\title{
Development of CTL-Based Reading Materials
}

\author{
Delsy Arma Putri, Atmazaki, Ermanto \\ Universitas Negeri Padang \\ delsyarmaputri@gmail.com
}

\begin{abstract}
The study aimed to describe developmont of CTL-based reading materials for junior high school students. The product of this research was a reading material of procedure text-based on CTL summarized in a booklet (textbooks) which are valid and practical. The Instructional design used $R$ and $D$ development model proposed by Plomp consisting of three steps: preliminary research, prototyping, and assessment phase. The results showed that CTL-based reading materials were very valid in terms of presentation, content feasibility, language accuracy, and display. Furthermore, the value of CTL-based teaching materials practicality reached very practical in terms of presentation, ease of use, readability, and the time spent in studying the reading materials. Based on the analysis and discussion, it was concluded that the developed CTL-based reading material is feasible to be used to help students improve their reading skills, especially in learning to read procedure texts. This reading material is expected to improve students' motivation, interest, and reading skill, as well as overcome the limitations of learning resources in the learning activities of reading procedure text.
\end{abstract}

Keywords-Reading Materials; Procedure Text; CTL

\section{INTRODUCTION}

Reading was one of the skills needed to shape literacy competencies that currently intensified by the government. Literacy defined as a person's skills (listening, speaking, reading, and writing) to communicate (USAID, 2014, p. 2). Thus, reading becomes necessary to build a literate society. The literacy movement was also intensified in schools, as one of the government's efforts to cultivate reading habits.

Reading habits were very influential on student achievement (Durgaiah, 2016, p. 655-661). One of them, reading plays an important role to improve the competence of science and mathematics (Akbaşli, et al., 2016, p. 108-121). Therefore, in Curriculum 2013, Indonesian subjects selected to integrate other fields of science, such as Natural Sciences (IPA) and Social Sciences (IPS). This was accordance with Rraku's opinion (2013, p. 1-4) which states reading not only improves the quality and quantity of knowledge, but the insights gained from reading can be applied in different studies or various academic subjects.

The purpose of reading were the students able to understand and respond to the content of reading correctly (Ameer, 2016, p. 2522); able to dissect the text to find its structure and characteristics, so that they understand the information and can compare the various types of texts (Nahotko, 2016, p. 732); and able to understand the sentences and structure of the text that has been read (Cagri, 2012, p. 91). However, this goal should be supported by the quality reading material.

Recognizing the reading importance for life, reading habits must be developed early (Dahlan, 2008, p. 21). However, based on current facts, the competence of Indonesian students in terms of reading relatively low. The results of Programme for International Student Assessment (PISA) initiated by the Organisation for Economic Co-operation and Development (OECD) stated that average scores obtained by Indonesian students in science, reading and math was ranked as 62nd, 64th and 63th of 70 countries evaluated (OECD, 2016 ). This fact supported by study Most Littered Nation In the World conducted by Connecticut State Univesity in March 2016. Indonesia was ranked as the 60 th of 61 countries on reading interest (Kompas, 2016).

Various problems reading, according to Aryaningsih (2013, p. 3) caused by several factors: 1) culture which still prioritizes oral culture than reading, 2) fewer teachers create the practice of reading, 3) the influence of electronic media and social media made children prefer to play the gadget than reading a book, and 4) lack of availability of reading materials in terms of both quantity and quality. In school, it affects the students' motivation to read, reading task only done when associated with the assessment (interviews with SMP 8 Padang teacher).

In relation of reading materials that used in schools, the results of observations on textbooks indicate: (1) learn sources was only textbooks provided by Kemendikbud (there was student books and teacher books); (2) there was no additional reading books for exercise materials in the classroom or library; (3) incomplete material, mostly there was just instructions that students should do; (4) teachers never developed their own reading materials which can support the curriculum. It made students less understand the purpose of the activities undertaken, so it was not aroused curiosity and motivation of students in learning. The same stated by Khaefiatunnisa (2015, p. 80-95) and Lestari (2016, p. 107).

Based on some of the issues described above, the specific problem of reading in schools was limited sources for students and teachers. The necessary effort to made learning resources available in schools was (1) relevant to the objectives of the curriculum, there was valid in terms of presentation, appropriateness of content, language, and graphics (Depdiknas, 2008, p. 28); (2) practical use by students and teachers, in terms of presentation, ease of use, 
readability, and time spent (Arikunto, 2008, p. 92). Reading materials with characteristics that were valid and practical, made the learning process take place with the draw, so the results also good.

Based on some of the issues described, the most fundamental problem in learning to read in schools was the limited source of reading materials for students and teachers. It takes effort to make a quality reading materials in school, including (1) relevant to the curriculum objectives, that was valid in terms of presentation, content feasibility, language accuracy, and display (Depdiknas, 2008:28); (2) practically used by students and teachers, in terms of presentation, ease of use, readability, and the time spent in studying the reading materials (Arikunto, 2008:92). The existence of teaching materials with valid and practical characteristics, make the learning process will be interesting, so the results also good.

In this study, developed reading materials of procedure text based on CTL for seventh-grade junior high school. The procedure text describes the steps-action or activity in sequence. The content of procedure text, made students understood the steps of an activity, such as cooked something, played something, and does an activity. In addition, students also creative by utilizing instructions or procedures for handicrafts made. Thus, the learning of procedural text was very useful for students daily life (Priyatni, 2014, p. 115; Kosasih, 2016, p. 45).

Specifically, the developed reading material was intended to support the curriculum, there was KI 3 on knowledge, KD 3.5 "to identify text procedures on how to do something and how to make (how to play a musical instrument/dance area) from various sources read and heard," and KD 3.6 "examines the structure and linguistic aspects of text procedures on how to do things and how to make (how to play musical instruments/dance areas, how to make regional culinary, make souvenirs) from various sources of reading and listening."

The development reading materials of procedure text following the contextual teaching and learning steps. As suggested by Sumardi (2000), teaching materials should develop based on specific learning approaches, thus had a definite basis and direction in learning activities at school. This approach was chosen in order to teachers can help connect the subject matter with the student's experience in real situations, so that students could see the relevance of the material learned in the classroom with the application in daily life (Berns and Erickson, 2001). Contextual learning was a learn to emphasize students' interests and experiences (Satriani et al., 2012).

Furthermore, the developed reading material should be appropriate in terms of presentation, content feasibility, language accuracy, and appearance, thereby enabling students to understand the information and ideas in the text that has been read (López and Medina, 2016). Teaching materials that developed should be assessed practically in order to use properly and support student learning activities (Plomp, 2007, p. 127). Thus, the formulation of this research problem as follows. "How does the process about developing reading materials of procedure text-based on CTL that valid (in terms of terms of presentation, content feasibility, language accuracy, and display), and practical (in terms of presentation, ease of use, readability, and the time spent in studying the reading materials) for seventh grade student at Junior High School?"

The purpose of this study was to explain the process of developed reading materials about procedure text-based on CTL that valid (in terms of terms of presentation, content feasibility, language accuracy, and display), and practical (in terms of presentation, ease of use, readability, and the time spent in studying the reading materials) for seventh grade student at Junior High School. Reading materials developed was expected to overcome the limitations of learning resources in learning procedures text. The materials expected to make learning more meaningful, useful for the progress of the activity and student learning outcomes.

\section{METHODS}

The Instructional design used $\mathrm{R}$ and $\mathrm{D}$ model proposed by Plomp consist of three steps: preliminary research, prototyping phase, and assessment phase. The product of this research was a reading material of procedure text-based on CTL summarized in a booklet (textbooks) that valid and practical for the seventh-grade student at Junior High School. Curriculum reference used was curriculum 2013. In 2013 curriculum, learning of reading contained on KI 3, which is understanding of knowledge (about factual, conceptual, and procedural) based on students' curiosity about science, technology, visual art, and visible phenomena. Meanwhile, KD used for learning to read procedure text is KD 3.5, and KD 3.6 which understand and examine the characteristics of procedure text.

Data analysis techniques used in this research was descriptive data analysis techniques which describe the validity and practicalities of reading materials developed. Validation related to the value about the feasibility of reading materials. The assessment carried out by filling a questionnaire validity by experts who experienced in order to know the weaknesses and advantages of the products developed (Sugiyono, 2010, p. 41). The validated aspect of reading materials was the feasibility of the presentation, content, language accuracy, and display (Depdiknas, 2008, p. 28).

Meanwhile, the practicality of reading materials relates to the convenience of teachers and students in using them. That was in line with Plomp's (2007, p. 124) opinion, a teaching material was practicable if used easily by teachers and students in learning. The practicality of reading materials could be known after the test. According to Daryanto (2013, p. 51-52), the intended test was to test the draft of validated reading materials. Practicality test of instructional material done by teacher and student after studying instructional from materials of procedure text developed. Teachers and students asked to complete a practicability questionnaire. 


\section{FINDING AND DISCUSSION}

Based on the design of development Plomp models, teaching materials of procedure text-based on CTL develop on three stages, (1) preliminary research, (2) prototyping phase, and (3) assessment phase. The results of this research described as follows.

This stage was the first step to collect and analyze information, define the problem, and plan the next activity. This stage was done by analyzing needs, analyzing curriculum, analyzing concepts, and analyzing students. The aims to establish the necessary requirements in the development of reading materials about procedure text based on CTL.

The results of needs analysis conducted with interviews and field observations indicate that learning resources were limited so that teachers and students need other materials that could motivate and associate learning with daily life. Furthermore, the results of analyzing the curriculum show the procedure text was in KI 3 knowledge, KD 3.5 and KD 3.6 which understand and examine the characteristics of procedure text. Then, the results of analyzing the concepts indicate that the learning procedure text begins from the meaning of procedure text, the function of procedure text, information in procedure text, the general characteristics of procedure text, the type of procedure text, examining structure of procedure text, and last examining the linguistic of procedure text. Furthermore, the result of student's analysis showed the maturity level and the students' experience, both as individuals and group was $80,94 \%$ with high category, the reading habits of student was 59,84\% with medium category, student reading interest level was $59,77 \%$ with medium category, psychomotor and social skill level of student was $72,66 \%$ with high category. Overall of preliminary research stage results could see in table 1 below.

Table 1

Result of Preliminary Research

\begin{tabular}{|c|c|c|c|}
\hline No. & $\begin{array}{l}\text { Steps being } \\
\text { taken }\end{array}$ & Instrument & $\begin{array}{l}\text { The results were used as a basis } \\
\text { for making reading materials }\end{array}$ \\
\hline 1. & $\begin{array}{l}\text { Needs } \\
\text { analysis }\end{array}$ & $\begin{array}{l}\text { The format of the } \\
\text { interview and } \\
\text { observation sheets }\end{array}$ & $\begin{array}{l}\text { Reading materials developed should be able to motivate and } \\
\text { associate learning with students daily life. }\end{array}$ \\
\hline 2. & $\begin{array}{l}\text { Analysis } \\
\text { curriculum }\end{array}$ & $\begin{array}{l}\text { Curriculum analysis } \\
\text { sheet }\end{array}$ & $\begin{array}{l}\text { Reading materials developed according to the Curriculum } \\
13 \text {, which is based on KI } 3 \text {, KD } 3.5 \text { and KD. } 3.6\end{array}$ \\
\hline 3. & $\begin{array}{l}\text { Analysis of } \\
\text { the concept }\end{array}$ & $\begin{array}{l}\text { Concept analysis } \\
\text { sheet }\end{array}$ & $\begin{array}{l}\text { The material in reading materials should be complete, } \\
\text { starting from the meaning of procedure text, the function of } \\
\text { procedure text, information in procedure text, the general } \\
\text { characteristics of procedure text, the type of procedure text, } \\
\text { examining structure of procedure text, and last examining } \\
\text { the linguistic of procedure text. }\end{array}$ \\
\hline 4. & $\begin{array}{l}\text { Analysis of } \\
\text { students }\end{array}$ & $\begin{array}{l}\text { Questionnaire } \\
\text { analysis of student }\end{array}$ & $\begin{array}{l}\text { Reading materials developed are tailored to the student's } \\
\text { age, students' social and cognitive skills, with an attractive } \\
\text { display and an easy-to-understand language. }\end{array}$ \\
\hline
\end{tabular}

Based on the preliminary research, reading materials of procedures text developed in accordance with the results of needs analysis, curriculum analysis results, concept analysis results, and student analysis results. The reading materials designed using CTL approach. This was in accordance with opinion Sumardi (2000), according to the teaching materials should be developed based on a particular learning approach so that the learning activities undertaken has a foundation and clear direction.

Second, prototyping phase. This phase was undertaken by designing reading materials then validated by experts and practitioners. There was three things that became basic references to develop these reading materials. First, the results of the analysis at preliminary research stage, there was a needs analysis, curriculum analysis, concept analysis, and analysis of the students, that used as one of the basic materials development. This means reading materials prepared an answer to preliminary research analysis. Second, the approach used in preparing reading materials is CTL consisting of constructivism, inquiry, questioning, modeling, community learning, authentic assessment, and reflection. CTL's used will be visible on the presentation of instructional materials, content, and evaluation. Third, the rules for composing the materials are guided by the structure, the principles of compilation, and the steps of writing the materials. By considering the basics, the materials could be arranged systematically.

After the materials finished, took validation. Validation took by filling out the validation questionnaire of reading material that given to experts and practitioners. Aspects assessed are aspects of presentation, content feasibility, language accuracy, and display of reading materials. The validation results of reading materials by experts can be seen in table 2 . 
Table 2

Results of Reading Materials Validity By Experts

\begin{tabular}{llccl}
\hline No. & \multicolumn{1}{c}{ Rated aspect } & Score & Validity Value (\%) & Category \\
\hline 1. & Contents feasibility & 63 & 87.50 & very valid \\
\hline 2. & Language accuracy & 24 & 100.00 & very valid \\
\hline 3. & Presentation materials & 80 & 100.00 & very valid \\
\hline 4. & Display of reading materials & 27 & 84.37 & very valid \\
\hline Overall validation & 194 & 91,50 & very valid \\
\hline
\end{tabular}

Furthermore, the validation results of reading materials by the practitioner can be seen in Table 3 .

Table 3

Results of Reading Materials Validity By Practitioners

\begin{tabular}{llccl}
\hline No. & \multicolumn{1}{c}{ Rated aspect } & Score & Validity Value (\%) & Category \\
\hline 1. & Contents feasibility & 10 & 83.33 & very valid \\
\hline 2. & Language accuracy & 11 & 91.66 & very valid \\
\hline 3. & Presentation materials & 16 & 100.00 & very valid \\
\hline 4. & Display of reading materials & 16 & 100.00 & very valid \\
\hline Overall teacher respons & 53 & 94.64 & very valid \\
\hline
\end{tabular}

Based on these data, the validity of reading materials by experts amounted to $91.50 \%$ categorized very valid. The validity of reading materials by the practitioner was $94.64 \%$ categorized as very valid. This was in accordance with the opinion Riduwan (2012, p. 15) which states that the value interval 81-100 very valid category. Thereby, reading materials of procedure text-based on CTL for the seventh-grade student at Junior High School already eligible materials consisting in terms of presentation, content feasibility, language accuracy, and display (Depdiknas, 2008, p. 28). Reading materials that worth it in terms of presentation, content feasibility, language accuracy, and display enable students to master the information and ideas in the text (López and Medina, 2016). Thus, the materials could be tested to the students and do an assessment to see practicality.

Third, the assessment phase. This phase done by assessing the level of practicality reading materials about procedure text. Practicalities of reading materials obtained after testing the product through one to one evaluation, small group discussions, and field test (the practicalities of reading materials by teachers and the practicalities of reading materials by the students overall). One to one evaluation took by practicing the materials to students who are capable, medium, and high. Small group discussion took by practicing the materials which have been designed for a group consisting of 5 persons. Field test took by a teacher and students who are 32 persons. Each student gets one material and uses them in the learning process. Test the practicalities of materials by students in all three phases is made after the students finished learning using materials. While the practicality of material assessment by teachers conducted during the learning takes place in this case, the teacher sees students learning with reading materials. Then, teacher assesses the practicality of teaching materials using a questionnaire that has been provided. Aspects considered in determining the practicality of teaching materials is the presentation, ease of use, readability, and the time spent in studying the reading materials. In summary, the results of one to one evaluation can be seen in Table 4.

Table 4

Results Practicalities of One To One Evaluation

\begin{tabular}{llccl}
\hline No. & Rated aspect & Score & Practicality value $(\%)$ & Category \\
\hline 1. & Presentation & 62 & 86.11 & very Practical \\
\hline 2. & Ease in Usage & 138 & 82.14 & very Practical \\
\hline 3. & Readability & 52 & 86.67 & very Practical \\
\hline 4. & Time & 27 & 75,00 & Practical \\
\hline \multicolumn{2}{l}{ Practicalities of One To One Evaluation } & 279 & 83.04 & very Practical \\
\hline
\end{tabular}

Furthermore, the results small group discussion can be seen in Table 5. 
Table 5

Results Practicalities of Small Group Discussion

\begin{tabular}{llccc}
\hline No. & Rated aspect & Score & Practicality value (\%) & Category \\
\hline 1. & Presentation & 114 & 95,00 & very Practical \\
\hline 2. & Ease in Usage & 260 & 92.86 & very Practical \\
\hline 3. & Legibility & 93 & 93,00 & very Practical \\
\hline 4. & Time & 56 & 93.33 & very Practical \\
\hline Practicalities of Small Group Discussion & 523 & 93.39 & very Practical \\
\hline
\end{tabular}

The results praticalities of field test by students can be seen in Table 6 .

Table 6

Results Pratikalitas Subjects By Students

\begin{tabular}{llccc}
\hline No. & Rated aspect & Score & Practicality value (\%) & Category \\
\hline 1. & Presentation & 735 & 95,70 & very Practical \\
\hline 2. & Ease in Usage & 1713 & 95.59 & very Practical \\
\hline 3. & Legibility & 613 & 95,78 & very Practical \\
\hline 4. & Time & 365 & 95.05 & very Practical \\
\hline Practicalities overall Instructional Materials & 3426 & 95.59 & very Practical \\
\hline
\end{tabular}

The results praticalities of field test by teacher can be seen in Table 7 .

Table 7

Results Pratikalitas Subjects By Teacher

\begin{tabular}{|c|c|c|c|c|}
\hline No. & Rated aspect & Score & Practicality value $(\%)$ & Category \\
\hline 1. & Presentation & 24 & 100.00 & very Practical \\
\hline 2. & Ease of use & 36 & 100.00 & very Practical \\
\hline 3. & Legibility & 8 & 100.00 & very Practical \\
\hline 4. & Time & 12 & 100.00 & very Practical \\
\hline Enti & practicalities Instructional Materials & 80 & 100.00 & very Practical \\
\hline
\end{tabular}

Based on the results of the assessment phase, the value practicalities of reading materials on one to one evaluation was $83,04 \%$ that categorized as very practical. Practicalities of reading materials on small group discussion amounting to $93.39 \%$ categorized as very practical. Practicalities of reading materials on field test by students reached $95.59 \%$ with a very practical category. In addition, practicalities of reading materials were also obtained from the teacher, equal to $100.00 \%$ categorized as very practical. Overall, every test of practicality, reading materials categorized as very practical. This was in accordance with the opinion Riduwan (2012, p. 15) states that the interval 81-100 categorized as very practical.

According to Plomp (2007, p. 127) practical reading materials can be used properly and support student learning activities. That was, reading materials of procedure text-based on CTL for the seventh-grade student at Junior High School already practical learning solutions and can be used by students and teacher in learning to read procedure text. Reading materials easier for students to understand the concept or learning procedure text. Reading material also has a high degree of readability. In addition, reading materials can help students to learn in a relatively short time. Students can take advantage of study time effectively.

\section{CONCLUSION}

Based on the results of the development was done, it can be concluded that the process of development of reading materials done through three stages are preliminary research, prototyping phase, and assessment phase has produced reading materials of procedure text-based on CTL were valid and practical.

First, designed reading materials have been declared valid in terms of presentation, content feasibility, language accuracy, and display. Reading materials, in terms of feasibility content, categorized as very valid by percentage $87.50 \%$. In terms of language accuracy, materials was very valid categorized by percentage $100.00 \%$. Review aspects of the presentation, materials categorized as very valid with a percentage of $100.00 \%$. In terms of display aspect, materials categorized as very valid with a percentage of $84.37 \%$. Overall, the validity of teaching materials amounted to $91.50 \%$ categorized as very valid. Based on the description that has been described, it can be concluded that the teaching materials designed valid and fit for use in learning to read procedure text. 
Second, designed reading materials have been declared practical. Rate practicality takes from one to one evaluation, small group discussion, and field test. Based on the results of one to one evaluation, practicalities of materials obtained by $83,04 \%$ categorized as very practical. Furthermore, practicalities of materials on small group evaluation amount to $93.39 \%$ categorized as very practical. Practicalities of materials on field test by students amount $95.59 \%$ with a very practical category. In addition, the practicalities materials were also obtained from a teacher, amounting to $100.00 \%$ categorized as very practical. Thus, reading materials titled Understanding and Exploring Characteristic Procedure Text for seventh-grade students at junior high school is a practical learning solution regarding the material of the procedure text. Materials easier for students to understand the concept or learning procedure text. Reading material also has a high degree of legibility. In addition, materials can help students to learn in a relatively short time. Students can take advantage of study time effectively.

Based on the conclusions that have been presented, submitted suggestions as follows. First, it is expected the teacher to be able to use teaching materials designed and developed it further in accordance with the needs of students. Secondly, it is expected the students to be able to use materials that are designed optimally so as to understand better the procedure text material. Thirdly, it is expected that other researchers to make research results for comparison and reference in conducting research related to the development of good reading skills as well as the implementation of procedure text-based CTL approach in reading materials.

\section{References}

Ameer, A. (2016). Developing the reading skills in english of students at college level: a task-based approach. International Journal of Applied Engineering Research. 11(4), 2522-2524. (C) Research India Publications. Retrieved from http://www.ripublication.com.

Akbaşlı, S., Şahin M., and Yaykiran Z. (2016). The effect of reading comprehension on the performance in Science and mathematics. Journal of Education and Practice. 7 (16), 108-121. Retrieved from http://www.iiste.org

Arikunto, S. dan Jabar, C. S. (2008). Evaluasi program pendidikan pedoman teoritis praktis bagi mahasiswa dan praktis pendidikan. Jakarta. Bumi Aksara.

Aryaningsih. (2013). Pengembangan bahan ajar membaca sastra Indonesia dan perangkat penilaian autentik siswa kelas VII Semester 1 SMP Negeri 8 Denpasar. E Journal Program Pascasarjana Universitas Pendidikan Ganesha. 2 (1), 1-11. Retrieved from http://pasca.undiksha.ac.id/ejournal/index.php/ jurnal_bahasa/article/view/551.

Berns, R. G. and Erickson, P. M. (2001). Contextual teaching and learning: Preparing students for the new economy. The Highlight Zone Research@Work. 5(1). Retrieved from http://www.cord.org/uploadedfiles/ NCCTEHighlight05ContextualTeaching Learning.

Çağnı T.M. (2012). Developing speaking skills through reading. International Journal of English Linguistics.2(6), 91. doi.org/10.5539/ijel.v2n6p91

Dahlan, M. (2008). Motivasi minat baca. Jurnal Iqra'. 2(1), 21. Retrieved from http:// portalgaruda.org/article.

Daryanto. (2013). Penyusunan modul (bahan ajar untuk persiapan guru dalam mengajar). Yogyakarta: Gava Media.

Depdiknas. (2008). Panduan pengembangan bahan ajar. Jakarta. Direktorat Jendral Pendidikan Dasar dan Menengah Direktorat Pembinaan sekolah Menengah Atas.

Durgaiah, P. (2016). Reading habits among student teachers with respect to gender and qualification, 3(4), 655-661. Retrieved from www.srjis.com.

Khaefiatunnisa. (2015). The effectiveness of contextual teaching and learning in improving students' reading skill in procedural text: a quasi-experimental study of the second grade students at one vocational school in Bandung. Journal of English and Education. 3(1), 80-95. Retrieved from http://ejournal.upi.edu/ index.php/LE/article/view/4612/0.

Kompas. (2016). Minat baca Indonesia ada di urutan ke-60 dunia. Retrieved from http://edukasi.kompas.com/read/2016/08/29/07175131/minat.baca.indonesia.ada.di.urutan.ke-60.dunia.

Kosasih, E. (2016). Mahir berbahasa Indonesia: untuk SMP/MTs Kelas VII. Jakarta: Erlangga.

Lestari, C. D. (2016). Pengembangan bahan ajar kontekstual untuk mata pelajaran IPS sekolah dasar. Jurnal Perspektif Ilmu Pendidikan. 30(3), 105-111. Retrieved from http://journal.unj.ac.id/ unj/index.php/ pip/article/view/2658.

López, M. B. (2016). Developing a CLIL textbook evaluation checklist. LACLIL, 9(1), 159-173. doi:10.5294/laclil.2016.9.1.7

Nahotko, M. (2016). Text genres in information organization. Information Research, 21(4), 732. Retrieved from http://InformationR.net/ir/21- 4/paper732.html (Archived by WebCite ${ }^{8}$ at http://www. webcitation. org/6m5HSCbu6).

OECD. (2016). "PISA 2015 results in focus", (Online). Retrieved from http://www.oecd. org/pisa/pisa-2015-results-infocus.pdf.

Plomp, Tj. (2007). Educational design: introduction from tjeerd plomp (eds). Educational \& training system design: introduction. Design of education and training (in Dutch). Utrecht (The Neterlands): Lemma Netherlands. Faculty of Educational Science and Technology, Universitas of Twente. 
Priyatni, E. T. (2014). Desain pembelajaran bahasa Indonesia dalam Kurikulum 2013. Jakarta: Bumi Aksara.

Riduwan. (2012). Skala pengukuran variabel-variabel penelitian. Bandung: Alfabeta.

Rraku, V. (2013). The effect of reading strategies on the improvement of the reading skills of student. Social and Natural Sciences Journal. 7(2), 1-4. Retrieved from www.journals.cz

Satriani, I., Emilia, E., and Gunawan, M. H. (2012). Contextual Teaching and Learning Approach to Teaching Writing. Indonesian Journal of Applied Linguistics. 2 (1), 10-22. Retrieved November 21, 2013, from http://ejournal.upi.edu/index.

Sugiyono. (2010). Metode penelitian pendidikan pendekatan kuantitatif, kualitatif, dan $r \&$ d. Bandung: Alfabeta.

Sumardi. (2000). Buku pelajaran Bahasa Indonesia SD sebagai sarana pengembangan kepribadian, penalaran, kreativitas, dan keterampilan berkomunikasi Anak. Jakarta: Grasindo.

USAID. (2014). Buku sumber untuk dosen LPTK: pembelajaran literasi kelas awal SD/MI di LPTK. Jakarta: RTI International. 